\title{
Knowledge and Opinion about Law (KOL) Research in Socialist Hungary
}

\author{
BaLÁzS FeKetE* \\ IsTVÁN H. SZILÁGYI**
}

\begin{abstract}
The critical assessment of the legacy of socialist jurisprudence is amongst one of the most difficult tasks of the post-transitory Central-European legal thinking. This study provides a critical reading of the findings of Hungarian socialist legal sociology with respect to the description and analysis of the socialist legal culture. The discussion starts with the first comprehensive empirical survey on the legal knowledge of the population, designed and carried out by Kálmán Kulcsár in 1965 and ends with András Sajó's synthesis on the nature of the Hungarian socialist legal culture elaborated in his monograph entitled Illusion and Reality in Law, published in 1986. The paper's main conclusion is that this two decades long 'golden age' of Hungarian legal sociology offers many valid points in both methodological and substantive terms contrary to the fact that the various findings were mainly elaborated under the pressure of official Marxism-Leninism.
\end{abstract}

Keywords: sociology of the law, legal sociology, knowledge and opinion about law, Hungarian legal scholarship, legal consciousness, knowledge about law, legal culture

\section{INTRODUCTION}

The problems of legal consciousness, ${ }^{1}$ legal culture from a contemporary aspect, constituted the first and most important research theme studied by sociological methods during the four decades of the socialist jurisprudence in Hungary. ${ }^{2}$ This was the first research project of the Hungarian legal sociology in the early $1960 \mathrm{~s},{ }^{3}$ and continued in several waves until the fall of the Socialist regime. Imre Szabó and Kálmán Kulcsár, ${ }^{4}$ the prominent figures of the

* Research fellow MTA-TK-JTI Budapest, senior lecturer ELTE-ÁJK Budapest. E-mail: Fekete.Balazs@tk.mta.hu. The original research was carried out in the frame of the OTKA research program, the legal culture of the Hungarian population - conceptual and empirical research [OTKA 105552]), while the publication of this paper supported by the programme of the Ministry of Justice for improving legal education in Hungary. The authors thank Masayuki Muriyama for his valuable comments on the earlier draft of this paper. A Hungarian version of this study was published in 2014: Fekete and H. Szilágyi (2014).

** Associate professor PPKE-JÁK, Budapest. E-mail: h.szilagyi.istvan@jak.ppke.hu

1 The research area on which this study focuses has been named by the abbreviation KOL inspired by the title of Podgórecki and his colleagues' famous volume, Knowledge and Opinion about Law. The study summarizing the results of the survey conducted in the 1960s by the members of the research group was published in 1973 and the expression has been used ever since to refer to research dealing with legal consciousness (KOL-research), and it is still one of the most cited basic studies of the topic. Cf. Podgórecki et al. (1973). For a critical survey of KOL research see BankowskiMungham (1976) 19-22., Tomasic (1987) 116-18.

2 The Communist takeover of legal academia occurred in 1949. Gyula Moór was forced to retire by 31 December 1948, and the practically unknown Imre Szabó was appointed as chair of the Department of Political and Legal Theory of the Law Faculty of ELTE. This was the final impetus for the internationally well-known Barna Horváth, considered to be the suitable successor of Moór, to leave the country. Cf. Szabadfalvi (1995) 150-51., H. Szilágyi (1995) 214.

${ }^{3}$ For a critical analysis of this process see Fleck (2004).

${ }^{4}$ For Kulcsár's career starting years see Varga (2013). 
socialist jurisprudence both rejected the 'bourgeois jurisprudence' in the spirit of breaking with the past. Their ambivalent attitude manifested in this relation would have been better characterised, borrowing from the Marxian phraseology, by 'eliminating preservation'. They in fact drew inventions from the earlier Hungarian traditions as well as from the contemporary 'bourgeois jurisprudence'.

Imre Szabó, who ensured the ideological background for KOL studies, whose ambivalence can be observed by his heavy criticism of his predecessors, especially Julius Moór and Barna Horváth, whilst he kept their ideas on the necessity of cultivating social sciences on an international level. ${ }^{5}$ After his appointment as the head of the Institute for Legal Studies of Hungarian Academy of Sciences (ILS) in 1955, Szabó continuously sought the possibilities of maintaining the international relationships of the Hungarian jurisprudence within the confined ideological frames.

The role of Barna Horváth is worth paying attention to, particularly in connection with Kulcsár, because Horváth had already studied the sociology of public opinion from the late 1930 s. ${ }^{6}$ He had made a survey on the possible personality traits of future lawyers among the law students at the University of Szeged in the beginning of the 1940s. ${ }^{7}$ This research was undoubtedly related to the problems of legal consciousness.

Kulcsár had been certainly inspired also by the tradition of ethnographic study of Hungarian folkways, the second period which had started in 1938 with the initiative of Miklós Hofer and István Győrfi and in which Kulcsár himself took part along with Ernő Tárkány Szücs and György Bónis. ${ }^{8}$

The 'Polish connection' had great importance regarding the impact of the contemporary Western jurisprudence, from the perspective of the Hungarian research. This meant that Kulcsár managed to integrate the Hungarian studies into an international network in which a researcher of a socialist country, Adam Podgórecki, professor of the University of Krakow, also participated with Western-European scholars. These international relations legitimized and helped to get the current findings of Western legal sociology and their Hungarian reception. ${ }^{9}$

Basic limitations should be kept in mind which arose from the socialist system. This paper will not emphasise the relatively well known ideological factors or those of the sociology of sciences. The strained circumstances were embedded in the observed social reality itself and stemmed from the fact that the Hungarian society was in a more or less subdued situation throughout the whole era. It was enforced into the frames of an artificially reduced and impoverished social structure and into a manipulated, one-way, 'short-circuit' system of communication. These problems will be readdressed in the review of the studies.

5 Imre Szabó carried out his legal studies at the Charles University in Prague in the middle of the 1930s, where he had the chance to participate at Hans Kelsen's lectures. While in a 1946 review he praised one of Moór's late works, in his 1955 opus magnum he discredited Moór as the 'official legal scholar of the Horthy-era.' Szabó's unquestionable authority acquired during the socialist era is shown by the fact that he was able to re-publish his work written in 1955 in 1980 as well. Cf. Szabó (1946), Szabó (1955). For the best summary of the subject see: Szabadfalvi (2004), Szabadfalvi (2003), Varga (2006).

${ }^{6}$ See: Horváth (1939), Horváth (1942), Horváth (1946).

7 See: Horváth (1942).

8 About Kulcsár's ambivalent relation to the ethnographic study on Hungarian folkways see H. Szilágyi (2002).

9 Cf. Podgórecki et al. (1973). 


\section{THE FIRST HUNGARIAN COUNTRYWIDE REPRESENTATIVE SURVEY OF LEGAL KNOWLEDGE}

Kálmán Kulcsár, having theoretically grounded the academic status of legal sociology in Hungary ${ }^{10}$ and with the agreement of Imre Szabó, started countrywide empirical research. The aim was to map the legal knowledge of the Hungarian population that, beyond the simple acquisition of information, touched upon several aspects of the essence of socialist law, e.g., to what extent the new, 'people's democratic laws' were successful or what type of the new legislation could not reach the population.

The questionnaire was designed by Kulcsár whilst the interviews were conducted by law students from Budapest, Pécs and Szeged in 1965. The final report, with the outcomes were summarized in charts with Kulcsár's foreword, was published by the ILS in $1967 .{ }^{11}$

\subsection{The sample}

Initially, the sample was defined as $n=1200$, but 1217 questionnaires were processed by the end of the research. According to the original plan, the legal knowledge of inhabitants of Budapest, other cities and of villagers should have been examined respectively in numbers of 650,430 and 120, and these figures were to be subdivided further with respect to occupational groups and age. These proportions slightly changed in the course of the research and 563 questionnaires were filled out in Budapest, 402 in other cities and 252 by villagers. Kulcsár explained these deviations due the numbers of the villagers had had to be raised because of a cancelled research program and several questionnaires had not been assessable. $^{12}$

It is worth mentioning Kulcsár's statements about the qualitative characteristics of the sample as it is not representative in regard to the whole population of the country. In his opinion, this would not be necessary to accomplish for the purpose of the research partly because the examination of legal knowledge, as a manifestation of the social consciousness, does not require the same exactness as the examination of other 'hard' social facts, e.g., the case of demography. ${ }^{13}$ Here the partial application of the mathematical rules of sampling is enough for grounding general conclusions. Furthermore, the aim of the research is not the overall description of the legal knowledge in Hungary but the demonstration and evaluation of the differences occurring among the examined social groups. ${ }^{14}$

There were several other characteristics of the sample further diminishing its representativeness. The sample involves only the jobholders. The respondents are divided

10 In the foreword of his pioneer work of the era called $A$ jogszociológia problémái (The problems of legal sociology) Kulcsár argues in favour of dealing with legal sociology in socialist jurisprudence because criticising bourgeois legal sociology is a necessity, especially for the sake of conducting Marxist sociology of a 'productive nature'; legal sociology has affected Marxist legal thinking as well and legal sociology, besides satisfying theoretical interests, is also important for practicing lawyers. Kulcsár (1960) 3-6. After publishing this volume Kulcsár reviewed several foreign articles in study-length writings, this way informing the Hungarian scientific public about the most recent results of legal sociology, e.g., Kulcsár (1962) (on Glendon A. Schubert: Quantitative Analysis of Judicial Behavior. Illinois, Glencoe, 1959.), Kulcsár (1964) (on W. M. Ewan (ed.): Law and Sociology. Glencoe, 1962.).

11 Kulcsár (1967).

12 Kulcsár (1967) 13-14.

13 Kulcsár (1967) 11.

14 Kulcsár (1967) 12. 
into three occupational strata: intellectuals, labourers and agricultural labourers. Kulcsár dismisses the idea of further sample divisions highlighting that its small number statistically makes it impossible. ${ }^{15}$ The sampling was also limited in geographical terms. Focusing only on three cities (Budapest, Pécs, Szeged) and four villages (Balástya, Görcsöny, Pécsudvard, Pusztaszer) as the researchers thought that this would correctly represent the settlement structure of the country. Moreover, it was necessary to raise the number of the villagers in the sample over their real proportion in the population, otherwise nearly all respondents would have been chosen from Budapest, because of the small number of the sample.

\subsection{The research postulates}

The presentation of Kulcsár's assumptions can show the important structural elements of the theoretical framework in which the research was done. Re-uniting these elements, a picture of the notions and suppositions with which the empirical findings were examined in the socialist jurisprudence of the 1960 s can be created. ${ }^{16}$

The theoretical starting point of the research is a truism today but it certainly was not in the heyday of 'socialist normativism' ${ }^{17}$ Both its content and implications were quite far from the official view as Kulcsár thought it was evident that the general awareness of the promulgated legal rules was a sheer fiction - the legal formulation and promulgation of a rule does not guarantee that it will reach the addressed people or, frequently, the society as a whole. ${ }^{18}$ Consequently, the research of legal knowledge is an indispensable scientific task.

The knowledge of law cannot be approached in a simplistic manner but should be examined in the most differentiated and sophisticated way. This idea is discernible through the whole project - Kulcsár distinguishes the 'layers' of legal knowledge from various points of view. For example, he creates a distinction between the knowledge of general and specific social strata, as well as, among the levels of knowledge of various branches of law and even of specific legal rules. He is continuously trying to synoptically look at the social and legal dimensions of the findings, as, in Kulcsár's eyes, only the comparison of these aspects can provide scientifically assessable information.

Kulcsár legitimises the research by stating that the governance of the society through legal rules 'requires the scientific inquiry of the knowledge of law'.${ }^{19} \mathrm{He}$ obviously tries to save legal sociology from the ideological suspicions, e.g., it is a 're-actionist' field of study, or it is 'functioning in such a way that weakens the official ideology'. He emphasises that the study of legal knowledge can contribute to the effective operation of the socialist system.

15 Kulcsár (1967) 12., 19.

16 At this point we have drawn inspiration from Oakshott's research methodology on the history of ideas. According to Oakshott, in the periods where public affairs started to be effectively dealt with (politics), in every case a specific 'dictionary' characteristic of the period has also developed, which made conducting debates possible and marked the frames of political thinking. Nothing prevents the development of such dictionaries in certain periods of scientific world, in other different areas of science. Cf. Oakeshott (2006) 40-41.

${ }^{17}$ For an outstanding introduction and ideological critique of socialist normativism see: Szilágyi (2003).

18 'The societal and state order, from the perspective of the security of law is naturally understood as a fiction, as it is apparent that proving the knowledge of law case by case would mean the failure of the application, the effect and functioning of law.' Kulcsár (1967) 7.

19 Kulcsár (1967) 7. 
Kulcsár chooses the survey method because of the lack of objective data. Only the number and content of the breaches of the law could be regarded as such data but the motivational base of infringements is so wide that the role of the legal knowledge would not be scientifically identified in it, he claims. A relatively high number of the sample also excludes the use of the method of content analysis. Kulcsár is naturally aware of the fact that the success of the research heavily depends on the construction of the questionnaire hence the detailed descriptions. ${ }^{20}$

Kulcsár defines the concept of legal knowledge by delimiting it from legal consciousness. This distinction is important, as, by doing so, he has opened a theoretical room for the later studies of legal consciousness that gained a considerably support in the 1970s. Legal consciousness is the more comprehensive notion that comprises the field of legal knowledge among other components and is basically the sum of 'all the notions that people hold about the current laws'. ${ }^{21}$ He uses the concept of 'everyday legal consciousness' on purpose, although he does not reflect on it specifically. Legal knowledge is an element of legal consciousness; it is itself a print of the social knowledge of law specified by the social stratification and the structure of law, which, besides other social factors, contributes to the constant formation of legal consciousness.

Kulcsár applies yet another distinction when he defines the concept of legal knowledge. Attributing an important, but not conclusive, role to the informational processes that convey the contents of rules to the addressees, he distinguishes two aspects of legal knowledge: the informational processes themselves; ${ }^{22}$ and the outcomes of these processes. ${ }^{23}$ Today these are called the dynamic and static view of legal knowledge. The extension of the notion, so as to include the dynamic aspect, allows him to magnify the scope of the study to take the problems of legal communication into account. ${ }^{24}$

Several notes that Kulcsár makes in the course of detailing the construction of the questionnaire show that he has certain preconceptions about the factors forming legal knowledge. It seems for him, these factors are the respondent's residence, gender, social position, occupation, participation in the work civil society organizations, reading legal rules, interaction with state organs and knowledge of politics. Kulcsár points out three groups of factors as the most important in the determination of legal knowledge: the respondent's sociocultural position, the level of knowledge and personal experiences with the legal system.

The final point in the discussion of Kulcsár's theoretical premises is that he could only rely upon a limited set of preliminary studies ${ }^{25}$ and he had no previous experience of conducting survey research.

In conclusion, it can be asserted that Kulcsár had a coherent and well elaborated conceptual view that stretched beyond the frames of the contemporary official Marxist jurisprudence in several aspects. The distinction between the knowledge of law and legal consciousness and the connection of the concept of legal knowledge to the informational processes were especially important premises. Kulcsár's work became the theoretical starting points of the later studies grounding a viable research tradition.

20 Kulcsár (1967) 9-11.

${ }^{21}$ Kulcsár (1967) 10.

22 Kulcsár (1967) 16., 32.

23 Kulcsár (1967) 10., 18-28.

${ }^{24}$ Kulcsár (1967) 28-29.

${ }^{25}$ He refers to two articles in particular: Studnicki (1965) and Kutchinsky (1966). 


\subsection{Methodology}

The research uses the well-known sociological method of scale calculation. The ideal level of legal knowledge, when all the respondents answer every question correctly, is 1 and the real level will show how far the number of the right answers approaches the ideal level. The actual level will always be less than $1 .^{26}$ The actual level of knowledge is obtained by dividing the number of wrong answers by the number of all questions and subtracting the quotient from 1.

\subsection{Outcomes}

The final result of the scale calculation of legal knowledge was 0.55 . This number in itself tells nothing about whether the level of legal knowledge can be regarded as high or low, this could be decided only after a multifaceted comparative analysis. It is important that the answers to the questions about the legal process itself were not included in the final result as Kulcsár left them out, asserting that they showed so great an alteration from the other data that it must have certainly been a random irregularity. ${ }^{27}$

Kulcsár thinks that the relationship between legal knowledge and consciousness can be demonstrated by the outcomes of the research. A picture can be drawn about legal consciousness if the answers given to the questions are examined that do not concern everyday life. If these answers, no matter whether they are right or wrong, show high level of accordance, i.e., not diverging with respect to the social stratification, then they will be manifestations of legal consciousness. The inquiry of legal knowledge could shed light on the various dimensions of legal consciousness, if the right questions are found. ${ }^{28}$

It is generally observable that the level of legal knowledge is the highest among the white collar workers and it gradually decreases among the physical workers and the agricultural physical workers. ${ }^{29}$ Thus, the assumed correlation between the social stratification and the level of legal knowledge is empirically verified. A similar correlation appears between the political and legal knowledge, although the level of the former is usually higher than the latter.

Taking a closer look at the various branches of law, Kulcsár points out that the highest level of concordance between the content of legal rules and legal consciousness can be found in the field of penal law. This is partly brought about by the moral embeddedness of criminal law and partly by the distinct attention of mass media directed to crimes. ${ }^{30}$ More divergences occur among the different social strata in the knowledge of civil law, nevertheless there are several areas where the answers are considerably congruent, e.g., the rules of loan, so the presence of legal consciousness is perceivable. Immediate practical experiences and belonging to certain professions can also exert a decisive influence on the knowledge of some legal problems.

Somewhat surprisingly the level of knowledge of constitutional and administrative law is the lowest in the 1960s' Hungary. Kulcsár asserts that this fact is due to the ineffectiveness of the communicational channels, e.g., newspapers, education, 'agitprop' activities, and also calls attention to the problem that the average person cannot clearly see their position in

\footnotetext{
${ }^{26}$ Kulcsár (1967) 17.

27 Kulcsár (1967) 18.

28 Kulcsár (1967) 21.

29 See: Kulcsár (1967) 19. Table 6.

30 Kulcsár (1967) 21.
} 
relation to the state organs. In his opinion, this latter effect is rooted in both the 'preliberation' (1920-1945) period and in the era of 'personality cult' (1949-1956). ${ }^{31}$ This general picture is tinged with an interesting fact, namely that the villagers' knowledge about the local state organs was exceptionally high. According to him, this is due to the living, face-to-face relationships between the council and the villagers that did not exist anymore in the greater communities (in the cities or the capital) in the $1960 \mathrm{~s} .^{32}$

The results clearly show that men's level of legal knowledge is higher than women's and women's political knowledge is also lower. It means that gender and gender related social roles influence the level of legal knowledge. ${ }^{33}$ It is no wonder that the highest difference between the levels of legal knowledge of the genders occurs in the field of constitutional law, especially if it is taken into account that women's political representation was rather low in the time of socialism. ${ }^{34}$ The geographic differences show that the lowest level of legal knowledge appears in the villages. Kulcsár emphasises that the villagers are disadvantaged in the access to legal information partly because they are relatively unschooled and partly due to their general cultural conditions. ${ }^{35}$ Finally, another somewhat surprising result is that age does not affect considerably the level of legal knowledge. ${ }^{36}$

Regarding the dynamics of legal informational processes, it is interesting that three quarter of the respondents had read legal texts, according to the results and it seems that reading law is a decisive factor in the knowledge of administrative law. Reading newspapers has a similar impact, albeit it improves legal knowledge in a more general way, because the vast bulk of legal information comes from court reports and journalism. ${ }^{37}$ Interpersonal relations also have an effect on legal knowledge as working in civil society organizations influences the level of knowledge and it can be practically seen as an informal channel of legal information. Among the institutional factors, the influence of the personnel (judges, jurors, lawyers) of the judicature has an outstanding effect disseminating relevant information to the laics, so the system of judicature also functions as an informational channel.

\section{THE QUEST FOR A THEORETICAL MODEL OF LEGAL CONSCIOUSNESS IN EMPIRICAL RESEARCHES}

Kulcsár left the ILS in 1969 when he was appointed as the head of the Institute of Sociology (IS). Afterwards, András Sajó, who started his career in the ILS in 1972, immediately after his university studies, became the key figure of the KOL studies in the next two decades. The ILS and the IS provided the institutional background for the second wave of the KOLstudies, which began in the early 70s and were financed from the "social consciousness studies' research fund. From a sociological point of view, the greatest achievement in this era was that the focus of studies moved from the relatively unproblematic theme of legal

31 Kulcsár (1967) 23-24.

32 Kulcsár (1967) 25.

33 At this point Kulcsár honestly talks about the relation between the existing social inequality of women and the lack of legal knowledge. Kulcsár (1967) 26.

${ }^{34}$ For a detailed assessment of the societal roles fulfilled by women in the times of socialism see: Tóth (2010).

35 Kulcsár (1967) 27-28.

36 Kulcsár (1967) 27.

37 Kulcsár (1967) 29-30. 
knowledge to the more sensitive topic of the inquiry of social morals and values of legal consciousness. This 'break-through' widened the scope of the research and made methodological experiments possible. It gradually distanced legal sociology from the Marxist legal theory which had become dogmatic and rigorous. These changes prepared the ground for Sajó's synthesis, Illusion and Reality in Law, which published in the mid 1980s, several years before the democracy. In this work, he criticized the socialist 'rule of law' and jurisprudence with an outsider's sour irony and shed light on the alarming symptoms of the Hungarian society's moral decline.

\subsection{The main trends of KOL studies in the $1970 \mathrm{~s}$}

One of the most important themes of the KOL studies was the examination of the ideas about criminal law as the criminological studies naturally joined legal sociology in this field. Some examples, in chronological order, were the audience poll of the Blue Light television programme $(1973) ;{ }^{38}$ the social strata surveys containing questions about penal law $\left(1975,{ }^{39} 1977,{ }^{40} 1979^{41}\right)$; the studies on the assessment of criminal law (1976-1977); ${ }^{42}$ the inquiries of criminal law's value system $(1978)^{43}$ and of the problems of victimisation (1982). ${ }^{44}$

Lots of research investigated how civil and family law was functioning, which was also of major importance for the inquiries of legal consciousness. Thus the examination of the sociological aspects of civil law litigation (1976); ${ }^{45}$ the evaluation of family law (19761977), ${ }^{46}$ and of the opinion on civil law (1983) can be mentioned.

Considerably less attention was devoted to administrative law (then 'law of state administration') and to constitutional law. There were already some questions were raised on labour law, what the socialist jurisprudence classified as a branch of the 'mixed special laws' containing elements of public law, in the Kulcsár-research and also in the later strata inquiries. However, these were concerned not so much with the legal consciousness but rather with the legal knowledge of labour law regulations. Looking back, this problem is easily explainable regarding the political and sociological conditions of the time. In the course of the 1975-76 strata surveys, the scholars tried to solve this problem by introducing the descriptive category of 'respect of state' in the research. ${ }^{47}$

The research themes were not exclusively shaped by the science-sociological factors but partly by the earlier findings and the issues of theoretical grounding. For example, it had

38 Dankánics and Erdősi (1974) VI. 8.

39 The legal consciousness of physical workers, 1975; control survey 1976. See: Sajó (1975b), Sajó, Székelyi and Major (1977).

40 The legal consciousness of economic leaders, 1977. See Sajó (1981a).

41 The legal- and value consciousness of caretakers - control group for the survey on the legal consciousness of physical workers, 1979. See: Sajó (1981b).

42 The evaluation of family- and criminal law, 1976-1977. For the results regarding criminal law see: Boros and Sajó (1983) 129-330. (Sajó's analysis).

43 The value system of criminal law, 1978. See: Vígh and Tauber (1983) 64-111.

44 The problem of victimisation, 1982. See: Korinek (1984); Korinek (1985); Korinek (1991).

45 The sociological aspects of civil law litigation, 1976. See: Kulcsár (1982) 203-29.

46 The evaluation of family- and criminal law, 1976-1977. For the results of the family law study see: Boros and Sajó (1983) 5-126.

47 Sajó, Székelyi and Major (1977) 86-88. About the notion of 'respect of state' see below section 3.3. 
been established in the previous legal knowledge studies that lay people knew hardly anything about that fields of law that were encountered very rarely in everyday life, especially procedural laws. On the other hand, due to the demand for a theoretical framework, the researchers tried to expand the scope of studies to be able to involve all the different fields of law and to discover the various factors influencing legal consciousness. For instance, scholars examined such factors as social stratification; ${ }^{48}$ belonging to a certain social group ${ }^{49}$ legal communication; ${ }^{50}$ legal socialization; ${ }^{51}$ and legal profession ${ }^{52}-$ all thought to influence legal consciousness.

\subsection{Methodological starting points and endeavours in theory construction}

There was no representative survey made regarding research methods following the comprehensive Kulcsár-research, ${ }^{53}$ although practically all the other statistical and social psychological methods were applied in the strata and social group studies. The methods of interview and document analysis were used along with the survey method. It can be concluded that, retrospectively, the methodological professionalism hardly seems to be questionable, apart from some uncertainties. ${ }^{54}$

One aspect of the theoretical grounding was the specification of the relations of these researches to Marxism, more closely to the Marxist jurisprudence. This would have required the establishment of a medium level sociological theory. Most of the studies dealt with social psychological problems and probably an interactionist theory could have been the right choice, which should have been connected to Marxist 'social theory' or jurisprudence. In strict scientific sense, this task was unsolvable, even incomprehensible. ${ }^{55}$ Fortunately Imre Szabó cut the 'Gordian knot' in Foundations of Marxist Jurisprudence, published in 1971. He devoted a whole chapter to the questions of legal consciousness from an emphatically Marxist perspective ${ }^{56}$ and with this work, Szabó legitimised the KOL studies and simultaneously identified and canonised the set of topics for the next generation of socialist jurisprudence to apply and later vary. ${ }^{57}$

Sajó, however, could not continue in the same vein as it took almost two third of Respecting Law and Social Behaviour, ${ }^{58}$ published nearly a decade later in 1980, to retread the path laid by Szabó. This was done to refresh the worn down phraseology and drawing

48 See Sajó (1975b), Sajó, Székelyi and Major (1977).

49 See Sajó (1981a); Sajó (1981b).

50 Besides Dankánics-Erdősi (1974), Neményi-Sajó (1984).

51 The problem of legal socialization. Survey conducted among four graders of ten secondary schools in Budapest and Pécs, and their parents and teachers (1982). Léderer and Sajó (1984).

52 Besides Léderer and Sajó (1984) see: the study of the legal consciousness of university students in Pécs (1985). Visegrády and Schadt (1985).

53 Although from reconstructing references it seems that the 1983 survey examining the opinion on civil law was representative to the whole population, these data were only partially used later.

${ }^{54}$ Such as the practice that Sajó (in the study mentioned in footnote 40.) merged the concepts of working groups and groups (from a sociological understanding), disregarding the fact that there was no interpersonal communication between the caretakers participating in the survey.

55 If we take into account the fact that Marxism was never a 'social theory', nor a science. In the Hungarian literature on legal theory see: H. Szilágyi (2003), H. Szilágyi (2004).

56 Szabó (1971) 197-300.

57 Just to mention a few relevant studies: Tamás (1969), Horváth (1969), Samu (1975).

58 Sajó (1980). 
inventions from George Lukács's ontology, as a reverberation of the 'renaissance that failed to come', using Tibor Hanák's words. ${ }^{59}$

Sajó himself was aware of the grotesqueness of the situation and this can be shown by quoting a phrase from a note added after a long Lukács citation 'We ought to beg the reader's pardon for these, maybe slightly scholastic references to authority and annotations but it could be decisive - before an unbiased court - that, contrary to the well-known behaviour-oriented concept of law, the outcome of the Marxist ontological approach is the same as that of the sociological one.' 60

Other researchers, who might have had less theoretical aptitude, solved the problem of the 'legal theoretical connection' of Marxist theory to sociology by applying the method of the 'red corner', generally used in the scientific world of the socialist era. A typical example of this is the study of József Vígh and István Tauber from 1978. The foreword of this study says 'These studies are all built on the Marxist thought that it is not people's consciousness that determines their existence but the other way around, it is social existence that creates and shapes people's consciousness.' [Highlights from the original text are neglected here.] ${ }^{61}$ This work then continued with more Marxist clichés for two paragraphs, emphasising that they follow the 'red path' laid down by Szabó. This is followed by purely intelligent, hardcore sociology, which has nothing to do with the thoughts expressed in the foreword.

The first phase of theory construction, the sociological grounding, has Sajó as the most prominent figure with a number of works, for instance: 'Legal Concepts in the Individual Mind' published in 1976, ${ }^{62}$ the second part of his treatise, published in 1980, titled 'Individual Conscious Respect of Law', ${ }^{63}$ and the seventh chapter of his volume published in 1986, titled 'Worlds of Beliefs - Outside the Door of Law', in which the results of his research are summarized. ${ }^{64}$ It seems proper to connect the more detailed account of these studies to the chronological survey of the empirical research to clarify the tendencies in theory construction.

\subsection{The 1970s - focusing on the social group and on the respect of law}

In 1973, a public opinion survey inquired about the evaluation of Blue Light, ${ }^{65}$ a popular television programme and its influence on the respondents. ${ }^{66} 1724$ people were surveyed by

59 See: Hanák (1979).

60 Sajó (1980) 54.

61 Vígh and Tauber (1983) 65. After this, they continue with more Marxist clichés for two paragraphs, emphasising that they follow the 'red path' laid down by Szabó. This is followed by purely intelligent, 'hardcore' sociology, which has nothing to do with the thoughts expressed in the foreword.

62 Sajó (1976).

63 Sajó (1980) 197-327.

64 Sajó (1986) 273-312.

65 The original purpose of the TV show, first broadcasted monthly, then every other week in the 1980s, was to inform the population about the work of law enforcement authorities - especially the police - and the most significant criminal cases. In the first part of the show the host discussed the general situation or major tendencies of crime with high-ranking state officials and the second part followed with news about different crime investigations, usually murder or other severe crimes. Sometimes this discussion involved interviews with the perpetrators. At the end of the show, the help of the audience was requested in ongoing investigations and/or in finding missing or wanted people.

66 Dankánics and Erdősi (1974). 
mailed questionnaires. However, this sample was not wholly representative because there was no television in some households at the time of the research.

The outcome of the research contributed to the better understanding of the structure of legal consciousness by corroborating the connection between anxiety and demand for punishment, which had already been presupposed in social psychology and legal sociology. Half of the viewers felt anxiety during the interviews made with criminals and this experience inspired hate against the perpetrators in more than sixty percent of viewers. Two third of the questioned viewers did not consider it important to respect the constitutional rights of the accused.

The study shed light on the influence of mass media on legal consciousness. The anxiety induced by the interviews with criminals, which were concentrating on the perpetrators' personality and on the detailed description on how they committed the crimes, overshadowed the effects of the news announced in the first part of the programme that usually emphasized the stability of public order and the efficiency of law enforcement. Less than one quarter of the respondents thought that the number of crimes had not been rising whilst $44 \%$ felt the situation worsened -in reality the number did not rise at all. At the same time, the program enhanced the viewers' inclination to stigmatise and shaped stereotypes, strengthening prejudices. ${ }^{67}$ The study, concerning the differentiated structure of legal consciousness, substantiated that the procedural rules of penal law were mostly unknown to the majority of viewers but they roughly knew the material rules of the penal law.

The main study of this decade was the survey of the legal consciousness of physical workers, conducted in 1975 and controlled in $1976 .{ }^{68}$ The aim of the research was to study three theoretical problems in an integrated way: How the social structure affects the individual legal consciousness; what psychological and social psychological factors contribute to the formation of individual legal consciousness and how the scope of Kulcsár's inquiries on the knowledge of law can be expanded. The theoretical clarification of the concept of legal consciousness was needed to be able to align this threefold problematic and to make it operational it for empirical study. This was accomplished by Sajó in the above mentioned essay published in $1976 .{ }^{69}$ The most important theses of the essay are enumerated below as follows: ${ }^{70}$

A distinction has to be drawn between the levels of social and individual legal consciousness. The former appears in the form of culture, folkways or in the public opinion. It has an external effect on the individual consciousness, albeit the existence of mutual influence between them is also evident. Social ideas, legal culture, legal folkways, about law are relatively well definable but the notions of individual mind reflecting on law are diffuse and inconsistent - regularity and logical consistency, the most important traits of the law as social objectification, are far from being characteristic of the individual legal consciousness. The psychological basis of the diffusion of legal notions in the individual mind is the lack of a 'personality function' corresponding to law. ${ }^{71}$

${ }^{67}$ Later, in the 1980s, Kék Fény largely contributed to the emergence of the notion of 'Roma crimes' and also their spreading among the population.

68 See: Sajó (1975b); Sajó, Székelyi and Major (1977).

69 Sajó (1976).

70 The original Marxist phrases and expressions are not used when reconstructing this line of thought.

71 At this point Sajó sharply criticises the view of Podgórecki and the Polish legal sociological school tracing back to Petrazycki, according to which there is a certain feeling of law or a sense of justice in individual legal consciousness that could be seen as a basis for an attitude referring to law. 
The social structure connects and pervades the social and the individual legal consciousness. The social position of the individual conclusively determines the intellectual and material conditions, which shape the individual's notions about law. The most prominent conditions among these are the cognitive, e.g. religious morals, classconsciousness, professional ethos, various subcultures, and the emotional factors of belonging to certain groups i.e., the desire for self-identification with the community.

The external manifestation of the individual legal consciousness is the opinion about law, though this can be only indirectly related to the evaluation of law and the actual individual behaviour can be seen even less as a straightforward consequence. The formation and disclosure of an opinion is an action itself with which the individual takes part in the communication in her narrower or wider social environment. However, this communication has its own psychical laws that can influence or 'distort' the formation of individual opinion. In this respect, the influence of the mass media is of great importance. The 'respect of law' appearing in the sociological inquiries about the general evaluation of law is, from the individual's perspective, nothing but the acceptance of the authority of the law-maker and the law enforcing state organs. This means that the study of the background political factors is also needed, along with the introduction of the 'respect of state' as an autonomous category besides the 'respect of law'.

Regarding the cognitive element of legal consciousness, knowledge of law does not conform in its structure to the law but shows the same diffusion as the legal concepts in the individual mind. The determining 'hard facts' of the individual's social position, gender, age, education, occupation, are conclusive for the level of legal knowledge. Besides these, belonging to social groups and individual experiences also affect the knowledge of law. However, the level of legal knowledge does not show a strong correlation with the measure of respect of law.

The empirical study ${ }^{72}$ surveyed 301 physical, skilled and unskilled, workers from Budapest and 136 agricultural physical workers in the basic sample of the 1975 survey. The sample was divided into 12 groups by age, gender and education for the comparative strata inquiries. ${ }^{73}$ The questionnaires were filled out by interviewers in the course of guided conversations. 50 law students were questioned in the autumn of 1975 and 40 skilled workers were re-questioned in the summer of 1976 for the control survey. The important sociological characteristics of the basic sample showed the effects of both the forced industrialization and the socialist 'rural development'. A significant percentage of the workers from Budapest were born in the countryside - they were first generation cityinhabitants. Moving into the capital was a more important reason for the mobility than preserving the former social status, e.g., $40 \%$ of the unskilled female workers found themselves in a lower status than their parents. The majority $(87 \%)$ of the respondents were married with the spouse's social status was generally equal or lower than that of the respondent - this factor diminished the heterogeneity of origin. Regarding socialization, the

72 Sajó, Székelyi and Major (1977).

${ }^{73}$ In the grouping by age they have distinguished between two groups: the 'old' (born between 1920-24) and the 'young' (1935-1939). This was important because the socialization of the 'old' group took place before and during the war, while that of the 'young' ones happened in the socialist era. In the category of profession (which partially involved education as well) they differentiated between unskilled, skilled and agricultural physical workers. 
characteristic method of parenting was the main way that usually leads to the formation of an 'authoritarian personality', borrowing the social psychology term. ${ }^{74}$

The researchers examined the effects exerted by legal experiences on legal consciousness at two different levels. At the societal level, they studied how those positive and negative historical events that were considered paramount in the given social stratus' view, e.g., socialist takeover, land reform, surrender of goods, show trials, had been interpreted in legal consciousness and the influence of the immediate experiences on legal consciousness was analysed at the individual level.

The researchers concluded that, regarding the influence of social experiences, the actual experiences 'rewrote' the past and these have primary importance as compared to the public opinion about the historical events. However, this statement could probably be reversed, if it is considered that while the injustice of the system of compulsory surrender of goods, no longer a taboo in the 1970s, after the consolidation of the Kádár-system, was remembered by $95 \%$ of agricultural workers whilst only $8 \%$ of the respondents remembered (or had the courage to remember) the show trials related to the 1956 revolution, which had been banished into the unconscious of the public thinking.

In the course of the investigation of individual legal experiences, the researchers separately looked into the effects induced by the experiences of contact with the courts and with the administrative state organs. At the end, they concluded that the effects of the experiences acquired in the courts outweighed the influence of contact with the administrative organs. ${ }^{75}$ The respondents often did not regard the latter as of legal quality, they did not have such clear memories and the evaluation of this kind of experience largely depended on whether the decision delivered by the state organ had been positive or negative.

The most interesting observation made during the study of the individual experiences, was the exploration of the individual's schizophrenic relation to law. While the respondents accepted the law at the 'official' level, when it came to their individual actions, individuals tended to evade it, keeping only their own interests in mind and repeatedly referring to fairness, as if they had been saying 'The law is right and it must be rigorously observed by everyone, except me. ${ }^{, 76}$

$7490 \%$ of the people present in the sample talked about experience coming from religious nurture, besides the generally applied physical abuse (even if it was only a slap in the face in $59 \%$ of the sample). The latter fact closely correlated with the harmonious or inharmonious nature of family life.

75 This was the case despite the fact that $45 \%$ of the sample had never been to a court. However, at the same time,. Only $16 \%$ of the polled had found the court's ruling unjust, moreover within this group a majority thought that only a factual mistake could have caused the negative decision, shows the authority of the courts. However, it is somehow puzzling that $41 \%$ of the young unskilled workers coming from Budapest has attended court in relation to a crime case, even if most of them was present not as a defendant but as a witness. This shows the morally degrading effect of the forced industrialization and the loss of traditional community bonds due to an artificial social mobilization coming along with it.

76 'We could see that even those people consider the court's ruling just whose interests are violated by the decision; the violation of interest rather results in helpless complaints. The concept of righteousness in light of this experience is divided even in the consciousness of individuals: on the one hand, if they evaluate the ruling as just (or lawful, or true, which is a prerequisite), they accept it due to its lawfulness, which does not prevent them from desiring another solution based on fairness. Instead of the synthesising nature of righteousness, in these divided consciousnesses the societal generality of lawfulness and the particularity of the morality of private interest coexists, and it does so 
The most important part of the study from a methodological point of view was the investigation of the respect of law. The researchers worked out a special method which, took the psychological mechanism of projection into account and made it possible to measure the respondents' legal knowledge and to characterise their legal consciousness from the aspects of tolerance and conformity at the same time. Bearing the outcomes of the earlier surveys on legal knowledge in mind, the researchers used facts of cases of penal law nature in the formulation of the questionnaire. The respondent was asked whether the law punished a given human act, which was followed by the question of whether this action should be punished by law in their opinion. On the basis of the answers, three factors could be compared: the actual legal regulation (A); the legal regulation presupposed by the respondent (B = 'subjective indictability') and its subjective evaluation $(\mathrm{C}) .{ }^{77}$ The level of legal knowledge could be ascertained by the comparison of the former two elements (A-B), while the respect of law could be assessed from the relation of the latter two (B-C). All this was completed by a categorization - 'labelling', 'moral' and 'deliberating' 78 - based on the content analysis of the responses, which aimed to show the motivations behind the respect of law. Taking these indicators into account, the sample could be characterised as follows.

The majority of respondents (56\%) turned out to be conformist, with one third $(31 \%)$ of the sample being non-conformist with the remaining $13 \%$ having no idea about the legal regulations. The vast majority $(87 \%)$ of the conformists belonged to the category of intolerants. The motivations of two thirds $(67 \%)$ of the conformist intolerants were 'labelling', while $70 \%$ of the tolerant non-conformists were 'deliberating'. The control

peacefully.' [Highlights in the original text] Sajó, Székelyi and Major (1977) 40. About the problem of the schizophrenic relation to law see below section 4.4.

77 Tolerant: the polled person does not consider the crime to be indictable. Intolerant: the responder considers the crime to be indictable. Conformist: the subjective evaluation matches the objective official indictability. Nonconformist: a subjective evaluation diverging from the objective official indictability. The answers can be divided into six groups based on these criteria:

- tolerant non-conformist: based on the assumed legal regulation the act is indictable, but the pollee would not do so.

- intolerant non-conformist: based on the assumed legal regulation the act is not indictable, but the pollee would do so.

- conformist intolerant: based on the assumed legal regulation the act is indictable and the pollee agrees.

- conformist tolerant: based on the assumed legal regulation the act is not indictable and the pollee agrees.

- tolerant: the pollee does not know what the law says about the crime, but she would not penalize the act.

- intolerant: the pollee does not know what the law says about the crime, but she would penalize the act.

${ }^{78}$ Labelling: the questionee when justifying their answers saw the violation of an abstract, but not moral, obligation in the action, or simply labelled it, or validated the suggestive reaction, e.g. in relation to homosexuality: homosexuals are 'dangerous', they have to be 'segregated', It is 'unnatural' etc.

- Moral: the responder mentions a certain moral motivation, e.g. homosexuality is immoral.

- Deliberating: the questionee did not refer to a general principle, but tried to take the circumstances of the case into consideration, to understand the motives of the perpetrator, or endorse a societal point of view, e.g. homosexuality is a 'private matter', 'we cannot have a say in it if they do it discretely.' 
surveys on law students and security guards corroborated that the tolerance indicator was strata specific - independent from the individual character - and increased with the education.

The researchers tried to substantiate their thesis on the strata specific nature of the tolerance-indicator by investigating the respondents' personality and tested the respondents' personal frustration tolerance (PFT). Their primary hypothesis was that those who tolerated frustration better would also tolerate with deviancy, and their demand for punishment would be less assertive. The outcomes of the tests showed the contrary - those who proved to be the most intolerant of deviancy were the best in dealing with frustration. ${ }^{79}$ The results of the PFT tests did not show any significant relation with the different motives. All led to the conclusion that the degree of tolerance of deviancy did not depend on the individual personality. The personality could only play a role in the extent of the individual's identification with the dominant ideas of their reference group.

In the course of the investigation of legal knowledge, the researchers extended the scope of the study to include three legal fields: penal law, private law and constitutional law. Penal law proved to be the best known to the respondents, in accordance with the previous expectations. In light of the outcomes, it seemed that the level of the knowledge of penal law was not influenced by education or gender.

The survey concentrated on family law and law of inheritance within private law, as the researchers believed that the personal experiences of the respondents would most enhance the legal knowledge in these fields. The results showed that the knowledge of civil law was considerably less than that of penal law. An interesting observation was that the level of legal knowledge was the highest among the older agricultural workers. The researchers explained this by stating that the civil law code had preserved the old legal traditions. Another curious finding of the survey was that the city dwelling women knew more about law than men.

The most astonishing result, however, occurred in the survey of the knowledge of constitutional law. Researchers posed the same question which had earlier been used in the Kulcsár-study, 'Who or which state organ makes the laws?', 30\% of the cityinhabitant physical workers and $24 \%$ of the agricultural workers, who belonged to the age group of the 1975 sample had answered correctly back in 1965 , while only $15 \%$ of the total sample knew the correct answer in 1975.

Maybe this stunning outcome or the above presented logics of theory construction induced the researchers to introduce the category of 'respect of state'. It is worth mentioning here that the 'respect of state' as a category had the same, although not so obvious, correlation with tolerance and motives in its tendencies as the 'respect of law'.

The researchers also tried to determine the characteristics of a 'general attitude' toward the law. Instead of using the Polish school's 'one question method', 'In your opinion, should the law be obeyed if it is corrupt?', which was heavily criticized, they divided the inquiry into three aspects: i. 'Is the law accessible?'; ii. 'Does the law produce angst?' and iii. 'How strong is confidence in the laws and law enforcement agencies?'.

79 Here, the researchers have disregarded the possibilities of interpreting the research results differently. It is possible, for instance, that the people tolerating frustration better might risk taking up more frustration with acting against deviant behaviour, than those people who do not care about deviant behaviour because they want to avoid the frustration that goes along with confrontation. Cf. H. Szilágyi (2012). 
The results indicated that for $(\mathrm{ad} \mathrm{i})$ the greater the role of personal experiences in the knowledge of law resulted in the less accessible the law was considered to be by the respondents. The anxiety (ad ii) did not depend on the social position but rather on the personal character and the confidence in law (ad iii), the 'labelling' respondents were strongly confident in the law, which was considered intolerant by them.

The research, conducted in 1976 and led by Kálmán Kulcsár, about the examination of the sociological characteristics of civil law litigations was related only indirectly to his earlier studies of legal knowledge and legal consciousness. ${ }^{80}$ The basis of the inquiry was the analysis of the judicial case flow statistics that was followed by the study of case materials using a prepared questionnaire. The cases were chosen from those which had been closed in 1976 and were collected from the district courts of five counties, Baranya, BorsodAbaúj-Zemplén, Csongrád, Szabolcs-Szatmár, Vas. ${ }^{81}$ From our perspective, the most important findings of the research can be summarised below.

The great majority of the cases were marital and other family related litigations. ${ }^{82}$ The litigants' occupational distribution showed that the agricultural physical workers were underrepresented, whilst the unskilled city-inhabitant physical workers were overrepresented in these legal disputes. ${ }^{83}$ This reinforced the earlier statements made about the alarming moral state of the stratum of unskilled physical workers. ${ }^{84}$

Interestingly, while the divorce cases constituted more than a quarter $(25,54 \%)$ of the litigations, the proportion of cases related to private rights was much lower (proprietary right disputes $4,6 \%$, trespass cases $4,3 \%$ ) and even the typical market related obligation disputes added up only to $11,15 \%$. Kulcsár explained this difference by the fact that the legal dispute could not be virtually avoided in the case of divorce. ${ }^{85}$ At the same time, this striking difference also indicated that the private property based market relations were pushed into the background in the socialist system. The low number of the property rights disputes showed that the litigiousness of the Hungarian population was low in this respect - at least, in comparison with what was generally believed about the earlier historical periods. This also meant that the inclination and the capacity for using legal means for the resolution of social conflicts decreased and, consequently, the confidence in law followed this tendency.

The methodology worked out for the examination of the legal consciousness of physical workers was applied in a survey in 1976-1977 conducted by Sajó and László

80 Kulcsár (1982) 203-29.

${ }^{81}$ The examined 14450 cases were studies based on different variables, such as the age, gender, profession or family status of the people participating in the lawsuit, or the subject, the process and the result etc. of the lawsuit. As most of the lawsuits concerned marriage, they applied a $20 \%$ sampling in this group of lawsuits.

82 The researchers put eight different lawsuit types here: for instance: divorce, paternity and descendence, maintenance of a child born in a marriage, maintenance of a child born outside of marriage.

${ }^{83}$ Agricultural physical workers representing only $13,1 \%$ of all litigants only appeared as $7,8 \%$ in the lawsuit group, while unskilled workers with a $30.4 \%$ representation formed $36,6 \%$ in this group of legal disputes.

84 'This phenomenon reflects the fact that in today's society the least balanced - and quite heterogeneous - stratum is that of the unskilled physical workers.' Kulcsár (1982) 208.

${ }^{85}$ However, one of the motives behind the constant growing of the popularity of common-law relationships since the 1980 s can be the possibility of avoiding the expensive and long divorce lawsuits. 
Boros. They extended the sampling to the whole population including all ages and occupational groups. Yet, the great number of the sample $(n=3500)$ meant they did not use the PFT test in the course of data collection and, only asked questions related to the fields of family and criminal laws for legal knowledge. ${ }^{86}$

Regarding the conformity and respect of law among physical workers (of all ages), the researchers found little difference from the results of the previous year. $56 \%$ of the respondents proved to be conformist, while $32 \%$ were non-conformist (only $1 \%$ higher than the previous year). This result was calculated on the basis of 2860 processed intelligible answers. There was, however, a considerable difference in the proportion of the intolerants within the group of conformist respondents - it turned out to be only $48 \%$, in contrast with the $87 \%$ that had been measured earlier.

With respect to the inquiry of legal knowledge, more or less the same outcomes came up as in the earlier studies. The knowledge of criminal law reached the highest level among all the investigated fields of law and it seemed to be independent from education. ${ }^{87}$ This was the first time when the researchers observed the phenomenon of 'normalisation' during the examination of the relation between the knowledge of criminal law and the psychological reflection on it. This means that the normative effects of social behaviour could corrupt the power of the legal norms over the individual's actions. ${ }^{88}$ The later studies also indicated the alarming tendencies of normalisation, especially in the case of bribery. It was interesting, too, that $44 \%$ of the population had felt the situation of criminality worsening in 1973 , while four years later their proportion reached $52 \%$.

Contrary to criminal law, the knowledge of private law proved to be rather dependent on education and more fragmented. The durability of the traditional patriarchal value system manifested itself in the fact that less than one third of the Hungarian population knew that both spouses were equally considered as the head of the family and two fifths of it had not heard about the concept of separate marital property.

The research of legal consciousness of economic managers, made by Sajó in 1977, had mostly a methodological importance. ${ }^{89}$ The small, non-representative sample $(n=136)$ of 'socialist enterprise' managers (CEOs) were asked to evaluate their agreement with 24 statements $^{90}$ on a 7-degree scale. The factor analysis of the data was carried out on a subsample of $n=59$, from which 8 factors were constructed, ${ }^{91}$ which gave the components of the managers' opinions on law. 'Legal opinion indicators' were created by weighting these factors and assessing their changing proportion. Finally, on the basis of these indicators, the researchers defined characteristic 'types of legal opinion'. ${ }^{92}$

${ }^{86}$ The two researchers published the results in a common, 330 page volume which contains many tables. Boros and Sajó (1983).

${ }^{87}$ However, the results showed that the criminal law knowledge of the agricultural physical workers and housewives was extremely low.

${ }^{88}$ In case of the non severe, work thefts only $43 \%$ of the population would have issued a penalty, while $11 \%$ did not condemn such actions at all.

89 Sajó (1981a).

90 E.g. 'A state enterprise can do anything law entitles it to do.' 'A human resource worker with the relevant experience knows labour law much better than a lawyer whose field of expertise is not labour law.'

91 The factors were divergence from law, corporate anti-formalism, cautiousness, overregulation, willing to apply the rules and the style of leadership.

92 The following types of legal opinion were identified as law-abider, cautious law-abider, nihilist, cautious nihilist, medium. 
The findings of this research are not surprising for an observer of today. The socialist economic managers in the second half of the 1970s were much more concentrating on a servient compliance with expectations coming from higher level (political) leaders ${ }^{93}$ than on respecting various peculiar legal provisions. Furthermore, it would have been very difficult to observe the law anyway due to the confusing over-regulation of the socialist economic sphere.

Another study, conducted a year later, by two criminologists, József Vígh and István Tauber on an almost representative sample, ${ }^{94}$ examined the social evaluation of the criminal law regime was closely connected to some parts of the 1977-76 survey that were concerned with criminal law. The researchers used layered sampling in which they complemented the first, randomly chosen sample in such a way as to make the sample representative for age, gender, education and the most important occupational groups. The questionnaires were filled out with the guidance of commissioners and 919 intelligible answers were processed. ${ }^{95}$ This data were evaluated from five viewpoints: i) the respondents' knowledge of criminal law; ii) their opinion about the ways and aims of punishment; iii) their evaluation of certain crimes; iv) their view on the situation of criminality and v) their opinion about the general preventive effect of punishment. The answers were analysed with respect to the respondents' gender, age, education and occupational groups and the findings, with particular importance for the present study, will be discussed below.

The researchers asked, in the course of the examination of legal knowledge (ad i), the respondents to define the concepts of law, crime and contravention and unsurprisingly, the proportion of the correct answers stayed below 5\% in all three cases. Nevertheless, the researchers, taking into account the 'not perfect but good' answers and those that 'contained correct elements', concluded that, even at this very abstract level, the concepts of contravention and crime were still more familiar to the respondents than that of law, because the respondents met these more frequently in their everyday life and in the media.

For ad ii, in relation to the evaluation of punishment system, the researchers inquired about the respondents' opinion on the aims and bases of punishment, the chances of the education of perpetrators and capital punishment. An interesting outcome was that nearly half of the respondents thought that most of or all the perpetrators were impossible to change by education, while in reality, according to the criminal statistics, two thirds of perpetrators had not become recidivist. Notwithstanding, the scholars explained this difference not by the recalcitrant prejudices of the population but by the distorting effect of the mass media. ${ }^{96}$

93 The indicator of the willingness of turning towards the leader seems independent of the divergence from law indicator. 'This independence means that the legal or illegal nature did not become significant in the case of the economic leaders unlike the hierarchical influence. To put it differently, the normative value system does not win over hierarchical power influences. This does not sound promising to a leadership system which would like to build on formal regulations.' Sajó (1981a) 617.

94 Vígh and Tauber (1983).

95 Sajó - although later he referred to the research results several times - harshly criticised the Vígh and Tauber survey on a methodological basis, both from the perspective of sampling and the method of questioning. Cf. Sajó (1980) 236. note 20.

96 ' $[\mathrm{But}]$ it is reasonable to think that the roots of this approach should be found within the distorted reflection of consciousness regarding crime. A major percentage of the population, when they hear the word 'criminal', think about the perpetrator of a severe, violent crime. This approach is 
The evaluation of certain crimes was examined by enquiring what kind of punishment the respondents would impose in six different cases: three crimes against life, two against property (petty embezzlement, petty larceny) and a case of espionage. $95 \%$ of the respondents chose punishments identical to those prescribed in the Criminal Code in 1973. It was also thought-provoking that $20 \%$ of the respondents would have also punished a mentally impaired perpetrator in the case of homicide.

It is suspected, once more, that the above mentioned distorting effect of the socialist communication structure when looking at the outcomes of the evaluation of the situation of criminality (ad iv). The respondents generally underrated the number of committed crimes. It fluctuated around 120-150 thousand per year in the previous decade, only 3 thousandths of the sample marked this number, and $47.5 \%$ of them felt a rising tendency in the number of crimes, contrary to the real situation of stagnation.

From a methodological point of view, it was remarkable that the researchers tried to explore those psychical motivations which may prohibit the commission of a crime (ad v). They presupposed that those people had a different psychical structure who had already been in a situation where they could have committed a crime ('criminalising situation') they had experienced a 'conflict of motives'. Therefore, the respondents were first asked whether they had been in a 'criminalising situation', ${ }^{97}$ and second, what kind of motivation could keep them from committing a crime. However, the outcomes showed no considerable difference between the two groups, in terms of the proportion of the different motivations, e.g., while $68 \%$ of the respondents who had already been in a 'criminalising situation' stated that mostly their conscience had prevented them from committing a crime and $74 \%$ of those who had not had such an experience answered the same. In light of these outcomes, the researchers' conclusion, which was a bit 'too nice', that is, that the preventive effect of potential punishment was overshadowed by the moral and other motivations, could not escape the contemporaries' criticism. ${ }^{98}$

The 1979 study by Sajó is mostly relevant from a methodological aspect. It examined the legal consciousness of caretakers in Budapest and, on the basis of this, the influence of the social group on the individual legal consciousness. ${ }^{99}$ The researchers processed the answers given in the guided interviews and the results of tests filled out by the respondents of the small $(n=91)$, not representative sample. Sajó tried to combine the methods used in the earlier strata surveys: the two-step interview method of the respect-of-law indicator and the factor analysis. Despite the complicated methodology, the study led to a very questionable conclusion, due to a trivial fault in the theory, as mentioned above, that contradicted all earlier Hungarian and international research findings. 'The group, this

also suggested by our mass communication devices. It has been discovered that, for example, $80 \%$ of the news broadcasting devices deal with violent crimes and their perpetrators, whereas the percentage of such crimes among the whole range of crimes is only $8-10 \%$.' [Highlights in the original] Vígh and Tauber (1983).

${ }^{97}$ Almost $62 \%$ of the pollees said that they have never experienced a situation urging them to commit a crime. However, there was a huge difference among those responding with a 'yes' to this question in terms of their gender: $52 \%$ of men, but only $23 \%$ of women remembered a criminalizing situation. In the age distribution, those between the age of 19-30 represented a high percentage.

98 Cf. Sajó's critique Sajó (1980) 236. However, a difference can be discovered behind Sajó's harsh critique which stood between the fairly optimistic view on the people of the two criminologists and that of Sajó's pessimist understanding of the homo kádáricus.

99 Sajó (1981b). 
'most social psychological' object of social psychology, does not seem to be a conclusive factor in the formation of legal opinion and unlawful behaviour.' 100 The most important outcome of the study was that the results of the PFT tests corroborated the observation of the 1975 strata survey, namely that the people who were more tolerant of frustrations, showed more intolerance of deviant behaviour.

\subsection{The new topics of the $1980 \mathrm{~s}$ - anthropological foundations and socialization}

Sajó's summary Respecting Law and Social Behaviour, mentioned above when discussing his aim to establish a legal theoretical foundation, was published in 1980. Here, he synthesized the international and Hungarian empirical findings in his chapter on legal consciousness. Moreover, he deepened the theoretical bases of the 1975 survey (presented earlier) and also explored several aspects of KOL researches not yet studied. Before taking a closer look at these aspects, it is worth making a detour to outline certain features of the image of the human psyche presupposed by these theoretical endeavours. This is important because this distinctive Hobbesian philosophical anthropology ${ }^{101}$ will give the basis for the firm critical attitude that has become more and more apparent in Sajó's theory in the next decade.

The classical view of the three constituents of the human soul are will, intellect and emotion. ${ }^{102}$ Sajó points out regarding the element of will 'I think that Ryle is right in regarding will as a cursed inheritance of the free will theories and in reconstructing it on the basis of cognitive and affective (weighting) elements and, therefore, we do not ascribe real independent existence to will.' 103 He declares, regarding will, that 'Rational consistency, as a social demand, is essentially limited to judging the others. The individual either cynically accepts factual inconsistency or methodically distorts their opinion towards the facade of rationalization.' 104 This statement means that the only available option for the individual is the subsequent rationalization. What kind of driving force then remains for the individual, lacking will and intellect? Nothing but the fear of the individual exposed to power, to the Hobbesian Leviathan. Add to this that Sajó rejects the idea that a distinct psychological motivation, as he included it several times in his Podgórecki-criticism, a particular 'sense of justice', would have to exist behind the law, the Homo kádáricus emerges - the coward mass-man who has no will, no intellect and no virtues whatsoever and who slavishly submits himself to power. It is another question how this image could be used ironically for the interpretation of the author's position. This disillusioned, pessimistic anthropology explains the exaggerated statements of Sajó, which even contradict empirical facts, e.g., the group does not influence the legal consciousness or that it is unacceptable that most people keep themselves from the commission of crime for reasons of conscience.

100 Sajó (1981b) 61. The insupportablity of this thesis might have also be seen by Sajó himself, as later on he has never referred to this research in this aspect.

101 The 'Hobbesian' attribute is not incidental. In the middle of the 1970s Sajó has indeed dealt with Hobbes's views intensively, along with political philosophical research and research on the history of ideas. See: Sajó (1974a); Sajó (1974b); and Sajó (1975a).

102 The classic threefold division of the human soul goes back at least as far as Plato in the history of European thinking. Cf. Plato: Republic. Book IV.

103 Sajó (1980) 230. note 8.

104 Sajó (1980) 238. [Highlights in the original]. 
At the same time, it must be mentioned that Sajó himself could not work out a consistent theoretical framework based on his anthropological presuppositions. His intellectual orientation changed subsequently and this self-destructive view gradually disappeared as Sajó was growing alienated from Marxism in the 1980s and his attitude became quite sceptical and critical of the socialist system. István Bibó's humanist historical philosophy probably also gave momentum to this transition. ${ }^{105}$

Thus, Sajó's first inconsistency with his anthropological presuppositions can be seen right at the start of his theoretical endeavour to explore the structure of legal consciousness, for he began his reasoning with declaring that to understand legal consciousness, one needed to examine those 'extraordinary situations' which required conscious, wilful decisions. The behaviour-influencing effect of law becomes visible only in this kind of situations, when the individual is enforced to renounce the comfort of habitual action. At the societal level, the number of 'extraordinary situations' is constantly growing with the historical process of modernization, going along with splitting up the traditional communities and diminishing the possibilities for habitual action. Probably, the source of Sajó's invention of this new theoretical starting point was Helmuth Schelsky's research ${ }^{106}$ and fortunately not Carl Schmitt's political philosophy.

Following this, Sajó explained his ideas about the structure of legal consciousness and legal knowledge; the distinction between the societal and individual levels and the influence of the individual's experiences on legal consciousness - all of which he had formulated at the beginning of the 1975 survey. Moreover, he started to pay new intellectual attention to the analysis of media effect on the opinions about law. He introduced the two-step information flow model, according to which the reputation of higher level mediators gave credit to the information for the recipients on a lower level. He also claimed that the informational monopoly of political power was closely connected to its legitimizing prestige. At the same time, he raised some counter-arguments to the idea of media influence. He pointed out the well-known difficulties of indirect communication whilst he emphasised that the law-abiding behaviour could exist without this kind of information and that the information about law could not be identified with the knowledge of law. In sum, he held the fairly exaggerated view that the acceptance of legal rules could not derive from communication.

The recognition of the influence of socialization on the formation of legal consciousness as an important aspect meant a substantive extension of the original theoretical foundations. Here, based primarily on Piaget's developmental psychology and on the findings of the contemporary political and legal sociological studies, Sajó discussed those elements of personality development in certain phases of socialization that were important for the observance of law.

In the summary of his otherwise thought-provoking discussion, Sajó managed to come up with rather laconic ${ }^{107}$ conclusions: 'Three immediate causes of the [...] observance of

105 Sajó explicitly refers to Bibó' study A kelet-európai kisállamok nyomorúsága in his writing published in 1986. Sajó (1986) 298.

106 In this work, Sajó did not refer to Schelsky at all, but it is certain that he knew his work because in a legal-sociological textbook edited by him, published a year before, one of Schelsky's studies was included. Schelsky (1979) For an analysis and further assessment of Schelsky's theory see: H. Szilágyi (2012).

107 As we saw earlier in the conclusion of the survey about the legal consciousness of caretakers (1979) Sajó discarded the influencing effect of the group. Opposed to this, one year later he writes in 
legal rules can be outlined: 1. the fear of sanctions; 2. rational deliberations; 3. the authority of legal rules. ${ }^{\prime} 108$

The KOL studies gradually lost their momentum in the next decade. This was partly due to both Kulcsár and Sajó turning their attention to the study of the socio-legal changes associated to the modernization process occurring in the second part of the 1980's. ${ }^{109}$ This tendency is clearly indicated by the outcomes of the survey on the evaluation of civil law, made in 1984, remained partly unprocessed and information about them can only obtained from Sajó's sporadic references in his work published in 1986. The last representative KOL research, conducted in 1986, became almost completely forgotten.

The final report of Pál Léderer and Sajó's study on legal socialization in 1982 also only remained in manuscript form. In the course of the survey, fourth grade secondary school pupils $(n=263)$ in Budapest and Pécs and some of their parents and teachers $(n=406)$ were asked about morally-influenced matters, e.g. abortion, medical gratuity, bribery by person in need. A new step was added to the earlier used, two-step interview method used. First, it was asked whether the current law punished the matter at hand; the respondent was asked whether they would punish the deed, ${ }^{110}$ and, finally, they had to give their opinion after they had been informed about what the actual legal regulation. It indicated the authority of positive law, if the respondent changed their mind in this third phase. For example, in the case of usucaption, $80 \%$ of those who had previously known this legal institution, considered it rightful, as compared to only $46 \%$ of those who had not. Nearly $40 \%$ of this latter group changed their opinion after been told about the legal regulation. ${ }^{111}$

László Korinek also did not publish his candidate's thesis - the empirical basis of which was a representative survey in Baranya county $(n=2448)$, using questionnaires sent via post. ${ }^{112}$ From the viewpoint of the KOL studies, the most important result of this study was the measurement of the population's evaluation of the situation of crime. In comparison with the results of the 1976-77 survey, the proportion of those who believed that the number of crimes was on the rise grew by $5 \%$ (up to $57 \%$ ) within the whole population. ${ }^{113}$

The Dankánics-Erdősi survey of the viewers of Blue Light (a TV-programme focusing on criminality), from a decade earlier, probably inspired the inquiry led by Neményi Mária and Sajó in 1984. ${ }^{114}$ However, this later study differed from the former research - it concentrated on the legal consciousness concerning private law instead of the penal system - but also in its sampling method and theoretical approach. This time, the researchers

one of his articles: 'The reaction of the reference group of the person to the potential breach of law is especially important.' Sajó (1980) 310.

108 Sajó (1980) 316. [Highlights in the original]

109 Kulcsár (1986); Kulcsár (1989); Sajó (1988).

110 In their personal opinion, $50 \%$ of the respondents diverging from the assumed legal solution would allow prostitution, $93 \%$ of students tolerated bribe taking into consideration the desperate situation of the briber, and $60 \%$ would allow constructions without permission. It is interesting to note that students decide on the case of defection more strictly (only 33\% tolerated it) than their teachers (about half of them tolerated it).

111 Typically, the students holding a position at the school - the future 'káders' - were more conformist than the others: they changed their opinion in a $61 \%$ ratio after getting to know the legal regulations.

112 Korinek (1984).

$11320-30 \%$ of the pollees assumed that they will be victims of a crime within a year, and $43 \%$ was afraid to walk around their homes at night.

114 Neményi and Sajó (1984). 
tried to assess the viewers' legal consciousness and the structure of everyday thinking about legal problems on the basis of the content analysis of viewers' letters to the television programme Legal Cases. ${ }^{115}$

Under the guidance of law professors, law students conducted the content analysis of randomly chosen 2538 letters, which were written to the 26 most popular broadcastings of the past years. The topics of the broadcastings eliciting the highest viewer activity were primarily cases of family and private law and, in a lesser part, of labour law. ${ }^{116}$ The researchers carefully studied not only the subgroups of the writers by age and gender but also the specific psychological state behind this sort of activity, which obviously differed from that of the respondents participating in a survey. ${ }^{117}$ On the basis of the content analysis, 20 variables of legal consciousness were distinguished ${ }^{118}$ and the most important factors of the acquisition of legal knowledge were separately examined. ${ }^{119}$

Two findings are worth pointing out here from the outcomes of the research. One insight was the distorting effect of the mass media, in so far as that the authors realised the problem that the primary aim of the broadcasting -to improve the viewers' level of legal knowledge and try to enhance their legal consciousness - was overshadowed by its latent, entertaining function. Secondly, the researchers also shed light on the particular relationship of law and morals 'An interesting lesson of the views mirrored in the letters is that the moral and the legal consciousness appear to run parallel to each other. As if the normative world of the moral values based on traditions or on interest-motivated customs had a separate life within the letter-writing society, the psychological authenticity and behaviourcontrolling force of which is evident for the writers.' ${ }^{\text {120 }}$

115 In the series starting at the middle of the 1970s mainly civil law and some labour law cases were introduced. They sometimes used captions taken at the 'crime scene' or interviews with the participation of the two sides to present the case. After this, they have presented letters coming from the audience, reacting to the cases previously presented, and the 'good solution' was introduced to the audience by one of the judges of the Supreme Court or a high-ranking official of the Ministry of Justice, who, after a while, became some sort of celebrities. As a result of this dramaturgic construction, the program started to resemble a quiz or an entertainment show. The popularity of the show is indicated by the fact that a part of the audience letters were written by groups of people gathered deliberately for this purpose.

116 The three most popular topics were, 'The unwanted child', 'The old husband' and 'Confiscating land'

117 'We can assume a certain type of 'letter-writer syndrome' which is in correlation with loneliness, the hindered nature of informal communication, hot-temperedness, neuroticism or the societal psychological state of 'infantilism' as called by Hankiss.' Neményi and Sajó (1984) 217.

118 These were apology; personal involvement; communication; favoring a solution through state intervention; highlighting personal problems in the case; penalty for the plaintive; penalty for the defendant; arguments for the solution - which were dissected into the variables of referring to negative social consequences, individual harmful consequences, authoritarian references and references to fairness - referring to precedent; bringing forward a personal case; change of situation; the relation between the TV solution and the individual solution (legal knowledge); legal references, attitude towards the protagonists; attribution; legal evaluation; and summarizing the variables of abstraction, deduction, induction in the index of the way of thinking.

119 When examining the main variables of the acquisition of legal knowledge, a result supporting the above mentioned claim of the 'letter-writing syndrome' emerged, as the three most important variables turned out to be the request to punish the defendant (occurring in $71 \%$ of the letters), the request to punish the plaintive (50\%) and highlighting a personal problem (34\%).

120 Neményi-Sajó (1984) 238. 


\section{ILLUSION AND REALITY IN THE LAW - \\ AN ATTEMPT AT THEORETICAL SYNTHESIS AND THE OUTLINES OF THE HUNGARIAN LEGAL CONSCIOUSNESS IN THE KÁDÁR-ERA}

Sajó published his Illusion and Reality in Law in 1986, having managed more than a decade of empirical study and theory building. ${ }^{121}$ The volume's claim for synthesis is evident from the title and no single chapter leaves no doubt. The parts of the book detailing the various fields of law - private, administrative and penal law - through the critical and comparative analysis of the relevant international scholarly literature have a rather synchronic nature. They can be seen as the diagnostic results of the legal system of the Kádár-era and of its functions and dysfunctions. ${ }^{122}$ The most essential chapter is the seventh, Worlds of Believes - On This Side the Door of Law. The author here endeavours to reconstruct the concept of legal consciousness, founding it on theoretical theses formulated on the basis of his own earlier research and can be considered as the summary of the theoretical findings of the Hungarian KOL studies gathering momentum in the 1970s. As such, it is of outstanding importance for the evaluation of the results of the socialist era.

Sajó's primary thesis is that the law generally plays a lesser role in the everyday life of the Hungarian society than would be expected from the outcomes of international studies and surveys. The Hungarian legal culture therefore is alienated from law, albeit this attribute is not exclusive to Hungary. ${ }^{123}$

The first step towards the explanation of legal alienation is the working out of an applicable model of legal consciousness which enables the theoretical location of the observed problems and the interpretation of data. Sajós concept of legal consciousness is built on three elements: (i) legal knowledge, (ii) the emotional-volitional and (iii) the evaluating elements. ${ }^{124} \mathrm{He}$ deals with them separately - although not hermetically separating them - using the critical perspective offered by the foreign literature and earlier research. As a result of this method, he is capable of giving a detailed picture about the elements of legal consciousness and about their functions and dysfunctions.

\subsection{The knowledge of law and the criticism of its studies}

Sajó first analyses the problems of legal knowledge. In his opinion, this category stands the closest to conventional legal thinking and has the greatest quantity of research material and experience available. ${ }^{125}$ Despite admitting the importance of legal knowledge in shaping legal consciousness, he remains pessimistic about the idea that through the study of legal knowledge "the build-up of reality [...] in social consciousness, originating in the world

121 Sajó (1986).

122 For example when analysing the housing situation of the 1970s Sajó highlights that it is actually an administrative question 'while the haunting of the civil law forms is an old-manly gesture towards the reigning or assumedly reigning forms of the legal system.' Moreover, the black market in the housing market emerges despite the strictest state supervision. Sajó (1986) 116-17.

123 Sajó (1986) 273. and 80-82. (Referring to Kulcsár the problem had already been outlined)

124 Sajó (1986) 274.

125 The former statement is true in international and also domestic aspects. This is because the results of Kulcsár's previously introduced research became known and appreciated in the professional circles in the following two decades, thus they directly and indirectly influenced later empirical research as well. See the part of the current study dealing with Kulcsár's research on legal knowledge. 
view of law and of legal system' can be grasped. ${ }^{126}$ This scepticism implicitly contradicts Kulcsár's conception that held legal knowledge as the researchable and quantifiable starting point for the study of social ideas about law. ${ }^{127}$

According to Sajó, the researcher has to face the following dilemmas in the course of studying legal knowledge:

(a) This kind of research has been done by lawyers and especially by scholars and students of law the outcomes is typically evaluated in the light of the idea of rightness. This is similar to university exams when the knowledge of law is measured on the basis of whether the answers are correct. ${ }^{128}$

(b) This kind of capability of thinking in legal categories, which is more or less evidently present in the case of the knowledge acquired in the course of legal education, is highly absent from everyday thinking. The common knowledge of law is basically (i) casuistic - not systematised; (ii) related to formal-legal elements, e.g., to a contract; (iii) formal legal roles, such as the roles of the judges or attorneys. The structure of ordinary knowledge of law differs in its nature from professional knowledge and is fragmented and often situational, in comparison to the latter. ${ }^{129}$

(c) The knowledge of the rules of law is not relevant in every case, for the citizens are not familiar with the abstract rules but only with rules applied in concrete situations, encountered in normative practices. They have knowledge regarding these and not about the black letter of law. Nevertheless, the social practices based on law can differ or surpass legal rules, as it has been indicated by a number of studies. That is why the explanatory force of the knowledge of abstract rule is seriously questionable from a legal sociological perspective. ${ }^{130}$

(d) Even if the citizens know certain rules, it is far from certain whether they know anything about the application of those rules. This, therefore, raises the question whether the sheer knowledge of the rules of law - supposing that the law is more than the sum of black letter law - means a real legal knowledge, whether it is relevant at all. ${ }^{131}$

(e) How far do the answers of the citizens reflect their real legal knowledge, because they could be distorted by several factors. Sajó underlines the factors of wishful thinking, the citizens' expectations to identify themselves with law and of fear. Here, the researcher has to face the impact of other, non-legal, dimensions of legal consciousness. ${ }^{132}$

(f) 'Pure' legal knowledge probably does not exist at all because the knowledge of law is often mixed with evaluative elements, similar to the previous point. Another influencing factor could be the respondent's opinion about the likelihood of a certain legal consequence, because the consideration of their own situation could alter their answers concerning legal knowledge. ${ }^{133}$

126 Sajó (1986) 284.

127 On the other hand, in a history of ideas sense Sajó's attitude shows that the domestic legal sociology has evolved a lot in two decades, because Sajó as a member of the next generation has simultaneously arrived at criticising the 'founding' results through integrating them, thus further developing the whole scientific area. This means that we have found a 'crossword puzzle solving' research in this case.

128 Sajó (1986) 274.

129 Sajó (1986) 275.

130 Sajó (1986).

131 Sajó (1986).

132 Sajó (1986) 275-76.

133 Sajó (1986) 277. 
(g) Sajó calls attention to legal knowledge being of a casuistic nature - it is shaped by a range of specific situations rather than by principles. This is why one cannot presuppose the existence of some abstract legal principles behind the answers concerning legal knowledge. ${ }^{134}$

It can be seen that Sajó regards the concept of legal knowledge as problematic as it is hardly compatible with the recent findings of social sciences, especially because it is not able to account for the social and psychological mechanisms of knowledge. ${ }^{135}$ Sajó himself sees the role of the research of legal knowledge in the study of legal consciousness as '[...] the organizing principles [of legal knowledge] do not empirically control legal consciousness - sometimes these principles are formulated only by mathematical-statistical analysis - but they could be useful as methodological constructions for the representation of the legal consciousness. ${ }^{136}$

\subsection{The emotional-volitional and the evaluative elements}

The emotional-volitional and the evaluative elements - the evaluation of the currently existing law and the ideas about a desired future law - make up the other part of legal consciousness. Less room is dedicated to these problematics in the 'theoretical part' of the seventh chapter in comparison to the critical examination of legal knowledge. Furthermore, these elements are often represented by Sajó with their mutual interconnections and will be approached in the same fashion here. The cause of this somehow less-detailed discussion probably is that there had not been such an elaborate tradition of the study of these dimensions of legal consciousness at the time, so the relevant empirical experiences and theories at hand were fewer than in the case of legal knowledge. Correspondingly, Sajó's argumentation here is descriptive rather than critical.

The underlying hypothesis is similar to what Sajo stated in the analysis of legal knowledge. He submits that the abstract, general questions have no relevance in this field, because both the acceptance and the evaluation of law could be interpreted from several angles. For example, citizens' acceptance of law can be studied at least from three points of view: (i) how far does they accept the law as the measure their own actions; (ii) in a given situation; (iii) and as a measure of others' behaviour.

Also, the evaluation of law is similarly complex because it can refer to (i) the evaluation of law in general or (ii) to the evaluation of certain legal institutions. Nothing can guarantee that the individual opinions, in these respects, will converge. ${ }^{137}$ So the correlation between the general evaluation of law and of the specific legal institutions is uncertain. It follows - in Sajó's opinion - that the study of legal intuition or the attitudes toward law, what he cynically called the quest for the philosopher's stone, can lead to dubious results as law can be the object of a general and public respect. This does not exclude the avoidance of law in specific situations - in the citizens' opinion. ${ }^{138}$

Another important aspect of the mapping of legal consciousness is the inclusion of the emotional elements. Emotions cannot be ignored, argues Sajó, because (i) they play a role in moulding the opinions about law; (ii) they can intensify the knowledge of law and, in

\footnotetext{
134 Sajó (1986) 277-78.

135 Sajó (1986) 277.

136 Sajó (1986) 278.

137 Sajó (1986) 278-79.

138 Sajó (1986) 279.
} 
this way, encourage the legal subject to act; and, (iii) they influence the reception of knowledge, e.g., up to the point where the knowledge of a given legal rule can depend on emotional motivations. However, this important dimension is pushed into the background and sometimes completely overlooked. It is a pity that Sajó, apart from mentioning this aspect, has not carried his studies further onto this interesting direction. ${ }^{139}$

Relying on the social psychological literature, Sajo calls attention to the problem that 'it is not enough to concentrate on concrete substances of mind' in the course of this study of the legal culture but 'we also have to observe those cognitive structures in which these substances are positioned and which determine the manner of their connections. ${ }^{140}$ He distinguishes the 'dogmatic mind' and the 'open mind' from this point of view. While the former tends to take only one point of view into consideration, which leads to dichotomies in the results, e.g. good or bad, the latter strives to free itself from the original circumstances and to find outside perspectives. These structures have outstanding importance in the reduction of reality, because the structural differences between the 'dogmatic mind' and the 'open mind' are conclusive in the determination of the mutual relations between legal knowledge and legal consciousness and of what kind of knowledge can be acquired, 'integrated', using psychological language, by the citizens. ${ }^{141}$

\subsection{The value and sense of KOL studies}

Sajó himself poses the question, after all this criticism, whether there is still a point in the KOL researches for the study of the law's everyday influence. ${ }^{142}$ His answer is fairly pragmatic - care must be taken with the results, because conclusions may not be easily drawn regarding the real influence of law from the attitudes deduced from the findings, as the opinion leaders play an essential role in the formation of these attitudes. Furthermore, it could be difficult to understand the reality of the law's influence that sometimes there might be a great distance between an individual's actions and their opinion and evaluation concerning law. Notwithstanding all these objections, Sajó claims that from the data collected by various KOL studies, partial knowledge of the role that the law plays in the social interpretation of reality can be acquired and, besides, a rather accurate picture on the mechanisms of the legal system can be obtained.

\subsection{The characteristics of Hungarian legal consciousness in the Kádár-era - deformity and alienation}

Sajó's starting point, as mentioned above, is that the Hungarian legal consciousness is foreign to law and, in this sense (along with a lot of other 'senses'), a Hungarian's views are profoundly differ from those of a citizen of a western country. 'It seems as if the legal interpretation of reality was not a part of our social culture, apart from legal life, in the strict sense of the word.' ${ }^{143}$ The underlying cause of this is that the law cannot be regarded as an organic element in the life of the citizens as a natural means of handling and resolving

139 Sajó (1986) 280. It has to be mentioned that researching sentiments has come into the centre of Sajó's scholarly interest after two decades, and then he started to deal with the problem in a nuanced frame, more thoroughly. See: Sajó (2011).

140 Sajó (1986) 280.

141 Sajó (1986) 281-82.

142 Sajó (1986) 282.

143 Sajó (1986) 309. 
conflicts. Only when the citizens want to invite the state to take part in their conflicts do they turn to the law. ${ }^{144}$ The law functions as an outside point of reference, which is able to draw the attention of the state organs to the citizen, which could eventually help settle any stalemate between the citizens.

Another deformity arises from the fact that the legal system of the Kádár-era hindered the enforcement of the subjective rights in numerous ways, as to diminish the chances of those who would try to assert or enforce these rights individually. In parallel, the importance of legal arguments became reduced, which in turn exerted a serious impact both on legal knowledge and legal consciousness. This is especially true in those situations when the citizen must face the power manifested in some state organ as the success of legal argumentation is hopeless for numerous reasons, 'begging, the gestures of clemencyseeking loyalty and references to fairness (not so much on the merits), or, at most, on equality are asserted.' 145

Sajó's final evaluation, which is very telling of the previously analysed legal consciousness in the Kádár-era, is that the reference to duty is the only dimension where '[...] the law can successfully enter [the everyday legal thinking, too] and this indicates the state of the legal culture, of legal consciousness and (partly) of the effective regulation. ${ }^{146}$

\subsection{The characteristics of Hungarian legal consciousness in the Kádár-era - conformity and nonconformity, tolerance and intolerance}

The Hungarian legal consciousness of the 1970s and 1980s can also be described from the perspective of legalism, with the help of the above mentioned characteristics, whether the law was approached with adherence or with criticism. Sajo first used these categories - the dichotomies of tolerance-intolerance and conformity-nonconformity with respect to law in 1975 when studying the blue-collar workers' legal consciousness. Here he completes the earlier data with the outcomes of a more recent survey on the evaluation of family and penal law provisions, conducted in 1983 on a fairly representative sample $(n=3000)$.

Interestingly. Sajó points out that 'the most prevailing standpoint is the adherence to the supposedly intolerant law' ${ }^{147}$ - this conclusion is worth special attention in the light of the above indicated problem of the Hungarians' legal consciousness, namely, the alienation from law. The vast majority of the Hungarian citizens (87\%) suppose that the law calls for punishment for a specific deed, even in those cases when the given deed is not punishable in fact. In half of the cases represented in the questionnaire, the described actions were not unlawful. Furthermore, it is also observable that a part of the population believes that the law is more severe than it is in reality and this is clearly related to their own generally punitive evaluation. On the other hand, most of those who wish the mitigation of a sentence usually did not agree with the given rule applied in the specific case in the first place.

The Hungarian population of the Kádár-era accepted the law and, indeed, in most of the cases, they hold it to be more severe than it is in the reality. The explanation of this is the desire to punish (punitivity) pervading the ranks of the population. This can be seen as parallel to the 'legal conformist - legalist' type described in France, which combines the 
acceptance and approval of law with a strong demand for punishment. ${ }^{148}$ In summary, it can be seen that a quite paradoxical situation emerges in the legal consciousness of the Kádárera - citizens generally seek to resolve their problems outside the law, nonetheless, they expect the law to severely punish others! A better example could not be found for the hypocrisy and schizophrenia on a social level that was so characteristic of the public thinking in general at the time. ${ }^{149}$

\section{SUMMARY: ONLY A DEAD LETTER?}

The evaluation of the 'socialist jurisprudence' and, thus, the establishment of some kind of relationship to it is not as an easy task as would seem at first sight. ${ }^{150}$ Quite complex problematic have to be faced in order to avoid the danger of simplification. That is why a comprehensive evaluation was not undertaken but instead, the outcomes exclusively from an outside, contextual point of view and from an inside, professional perspective have been considered.

\subsection{The contextual perspective}

Kulcsár's study, conducted nearly half a century ago, is relevant because of its novelty, courage and its findings. It is also important for the development of the Hungarian empirical legal sociology for two other reasons. The first is a historical one. A closer look at its methodology and results reveals that this study had opened a broad room for the later empirical researches and had also provided a conceptual framework for them. This is why the separation of legal knowledge and legal consciousness and the distinction between the dynamic aspect of legal knowledge and its static description were so crucial. The possibly unintended fruitfulness of Kulcsár's theoretical endeavours has been proved by the sheer number of the later researches.

Sajó's works, due to the sharp critical sense of the author, brought the hypocrisy of the legal consciousness of the Kádár-era to the surface. However, it has to be pointed out that by exploring the inner contradictions - alienation from law versus strong demand for punishment - of the Hungarian legal consciousness, he detected a more fundamental, 'evergreen', characteristic feature of the Hungarian attitudes towards law, which probably dates back to the second half of the $19^{\text {th }}$ century. When Sajo studied this problem in the context of the post-1956 socialist period, he himself emphasised its similarities with the traditional Hungarian peasant views on law in the inter-war period - quoting Ernő Tárkány-

148 Sajó (1986) 293.

149 Based on a wide-spread survey conducted in December 1986 by TÁRKI, Sajó thoroughly analysed the population's consciousness of rights with the SPSS program - a very modern tool for the time. The results of the empirical research converge with the conclusions of Látszat és valóság: the legal culture of the late Kádár-era is very far from a 'western-pattern' legal culture, in which one of the determining elements of the societal functioning of law is formed by the civil assertion of legal claims. In Sajó's words: 'The claim for right is pragmatic, the recognition of basic legal protection and the validation of human dignity to everyone is almost absent from it, it is characterised by primitive rebellion and practical submissions without making the authoritarian legitimacy of the law enforcement bodies questionable.' Sajó (1988-1989) esp. 145-174. (quote from: 173.)

150 For a presentation of the distinct approaches see, for example, the studies of Péter Cserne, Miklós Szabó, Péter Szilágyi or Csaba Varga. Cserne (2004); Szabó (2004); Szilágyi (2004) and Varga (2004). 
Szücs's ${ }^{151}$ and Ferenc Erdei's ${ }^{152}$ works about this subject. He also tended to accept the idea of the survival of these mental structures, ${ }^{153}$ which were shaped much earlier.

Finally, the KOL studies, which had been started by Kulcsár's investigations, were continued later by an increasingly wider scholarly community and had even gained Imre Szabó's approval and theoretical support. They became an essential field of socialist legal theoretical reflexions. The reliance on facts and the up-to-date reviews of the international scholarly literature ensured the compliance with high academic standards and the possibility of criticism.

\subsection{The professional aspects}

Finally, the scholarly aspects of the Hungarian KOL studies can be approached from three prominent perspectives.

First, it is worth considering those dimensions of legal consciousness that were investigated thoroughly in the course of these more than two decades of study. These are the following:

(i) The psychological (PFT test) and social psychological structure, indicator of the respect of law, the motivations of law-abiding behaviour, demand for punishment, the relations of legal consciousness - opinion - behaviour, normalization, legalism, of legal consciousness;

(ii) The relations between legal knowledge and legal consciousness;

(iii) The influence of social structure on legal knowledge and consciousness;

(iv) The survey on the legal knowledge of various branches of law (criminal, family and civil law).

Secondly, there are other fields beyond these that were only touched upon occasionally but not explored in details, such as:

(i) The impact of mass media on legal consciousness;

(ii) Legal socialization. Sajó wrote about the theoretical aspects of this in his work published in 1980 and see also the empirical study of secondary school pupils conducted in 1982 ;

(iii) Historical experiences. This theme emerged in the 1975 study of the physical workers' legal consciousness;

(iv) The social groups' influence on individual legal consciousness, e.g., the controversial conclusions of the methodologically mistaken survey on caretakers' legal consciousness;

(v) The relationship between the 'respect of state' (politics) and law in legal consciousness;

(vi) The schizophrenic separation of law and morals;

(vii) The legal knowledge dimension of labour law.

Finally, it should be mentioned the following topics that could have been raised but remained neglected in the researches (mainly due to the above described ideological and historical context):

(i) The relations between the social value system and the system of legal attitudes;

(ii) The connections between the social character (mentality) and legal consciousness;

(iii) The problems of legal culture.

151 Tárkány-Szücs (1981).

152 Erdei (1974).

153 Sajó (1986) 298-99. 
Our response to the starting question raised above in the subheading is a definite 'no' in the light of what was discussed earlier. The KOL studies of the socialist era created a tradition that can be continued today. This tradition offers an excellent starting point for comparative studies in terms of the empirical data, methodology and theoretical conceptions. One of the most interesting questions for the resumed studies could concern the extent of the influence of the post-1989 political, social and economic changes on the legal consciousness of the Hungarian population on the one hand and, vice versa, the extent to which the schizophrenic mind set of the legal consciousness of the Kádár-era has influenced the formation of these new social structures on the other hand. It can only be hoped that the newly resumed KOL studies may reach again the level of intensity of the studies in the 1970s-80s.

\section{LITERATURE}

Bankowski, Zenon and Mungham, Geoff, Images of Law (Routledge \& Kegan Paul 1976).

Boros, László and Sajó, András, A család és a családi jog megjelenése az állampolgárok tudatában. Jogtudat, jogismeret (Family and Family Law in the Consciousness of the Citizens. Legal Consciousness and Knowledge about Law) (MTA Szociológiai Intézet 1983).

Cserne, Péter, 'Gazdaság és jog viszonya a marxista jogelméletben és a jog gazdasági elemzésében' (The Relationship between Economy and Law in the Marxist Legal Theory and Economic Analysis of Law) (2004) 4 Világosság 49-63.

Dankánics, Mária and Erdősi, Sándor, A „Kék Fény” közvéleménye. Egy közönségkutatás tapasztalatai (The Public Opinion of the "Blue Light". Experiences of an Audience Survey) (MRT TK 1974).

Erdei, Ferenc, A magyar falu (The Hungarian Village) (Akadémiai Kiadó 1974).

Fekete, Balázs and H. Szilágyi, István, 'Jogtudat-kutatások a szocialista Magyaroszágon' (KOL Researches in the Socialist Hungary) (2014) 4 Iustum Aequum Salutare 5-40.

Fleck, Zoltán, 'Szocialista jogelmélet és szociológia' (Socialist Legal Theory and Sociology) (2004) 4 Világosság 65-77.

H. Szilágyi, István, 'Dráma és jogfilozófia Horváth Barna életművében' (Drama and Legal Philosophy in the Oeuvre of Barna Horváth) in Loss, Sándor et al.: Portrévázlatok a magyar jogbölcseleti gondolkodás történetéböl (Bíbor, 1995) 211-66.

H. Szilágyi, István, 'Let Us Invent the Hungarian Legal Anthropology’ (2002) 33 Rechtstheorie 18796.

H. Szilágyi, István, 'A marxista társadalomtudományi fogalmak használhatatlansága' (2003) 4 Jogelméleti Szemle <http://jesz.ajk.elte.hu/hszilagyi16.html> accessed 23 October 2017

H. Szilágyi, István, 'A marxista társadalomtudományi fogalmak használhatatlansága' (2004) 4 Világosság 79-88.

H. Szilágyi, István, 'A jog lélektani alapjai' (Psychological Bases of Law) in H. Szilágyi, István, (ed.), Társadalmi jogi kutatások. Egyetemi jegyzet (Szent István Társulat 2012) 102-16.

Hanák, Tibor, Az elmaradt reneszánsz, 1-2. A marxista filozófia Magyarországon - Történelmi áttekintés/Rendszeres áttekintés (The Cancelled Renaissance, 1-2. Marxist Philosophy in Hungary. A Historical and Conceptual Overview) (Európai Protestáns Magyar Szabadegyetem 1979).

Horváth, Barna, A közvélemény ellenörzése (The Control of Public Opinion) (Magyar Királyi Ferencz József Tudományegyetem 1939).

Horváth, Barna, A közvélemény vizsgálata. Die Unterschung der öffentlichen Meinung. The examination of public opinion (Univ, Nagy Jenö 1942).

Horváth, Barna, 'A láthatatlan ember' (The Invisible Man) (1942) 6 Délvidéki Szemle 226-33.

Horváth, Barna, 'A közvélemény megszólaltatása' (Giving Voice to the Public Opinion) (1946) Közvélemény. A Magyar Közvéleménykutató Intézet Szemléje 3-5.

Horváth, Tibor, 'Jogismeret és büntetőjog' (Knowledge about Law and Penal Law) (1975) 12 Államés Jogtudomány 405-28. 
Korinek, László, A látens bünözés vizsgálata (Study of Latency in Criminality) (1984) [unpublished doctoral thesis (candidature)].

Korinek, László, 'A magyar népesség viktimizációjának néhány aspektusa' (Some Aspect of Victimization of the Hungarian Population) (1985) 40 Jogtudományi Közlöny 10-14.

Korinek, László, 'Victimization, attitudes towards crime and related issues. Comparative Research Results from Hungary' in Arnold, Harald (ed.), Victims and Criminal Justice (Max-Planck Institute 1991) 45-99.

Kulcsár, Kálmán. A jogszociológia problémái (Problems of Legal Sociology) (KJK 1960).

Kulcsár, Kálmán, 'Matematikai módszerek a jogtudományban' (Mathematical Methods in Legal Studies) (1962) 5 Állam- és Jogtudomány 568-78.

Kulcsár, Kálmán, 'A jog és a szociológia' (Law and Sociology) (1964) 7 Állam-és Jogtudomány $635-42$.

Kulcsár, Kálmán, A jogismeret vizsgálata (Study of the Peoples' Knowledge about Law) (MTA-JTI 1967).

Kulcsár Kálmán, Társadalom, gazdaság, jog (Society, Economy, Law) (Közgazdasági és Jogi Könyvkiadó 1982).

Kulcsár Kálmán, A modernizáció és a magyar társadalom (Modernization and the Hungarian Society) (Magvető 1986).

Kulcsár Kálmán, A modernizáció és a jog (Modernization and Law) (Közgazdasági és Jogi Könyvkiadó 1989).

Kutchinsky, Berl, 'Law and Education: Some Aspects of Scandinavia Studies into the "general Sense of Justice«' (1966) 10 Acta Sociologica 21-41.

Léderer, Pál and Sajó, András, Kutatási összefoglaló a jogi szocializáció vizsgálatról (Research Report on the Study of Legal Socialization) (1984) [manuscript].

Neményi, Mária and Sajó, András, 'Levelek a TV „Jogi esetek” c. műsorához' (Letters to the TV Program "Legal Cases") (1984) 27 Állam- és Jogtudomány 208-44.

Oakeshott, Michael, Lectures in the History of Political Thought (Imprint Academic, 2006).

Podgórecki, Adam et al., Knowledge and Opinion about Law (Martin Robertson 1973).

Sajó, András, 'Miért nem természetjogász Thomas Hobbes' (Why cannot Hobbes be regarded as a Natural Law Thinker?) (1974) 17 Állam- és jogtudomány 101-20.

Sajó András, 'A szuverén és az alattvaló helyzete Thomas Hobbes felfogásában' (The Position of Sovereign and Subjects in the Conception of Thomas Hobbes) (1974) 17 Állam-és jogtudomány $480-501$.

Sajó András, 'Az engedelmesség és korlátai' (Obeisance and its Limits) (1975) 18 Állam- és jogtudomány 159-89.

Sajó András, ‘Empirikus elővizsgálatok a jogtudatról' (Preparatory Studies on Legal Consciousness) (1975) 18 Állam- és Jogtudomány 464-74.

Sajó András, 'Jogi nézetek az egyéni tudatban' (Legal Ideas in the Individual Consciousness) (1976) 19 Állam- és Jogtudomány 419-43.

Sajó, András, Székelyi, Mária and Major, Péter, Vizsgálat a fizikai dolgozók jogtudatáról (A Study on the Legal Consciousness of Blue-Collar Workers) (MTA ÁJTI 1977).

Sajó, András, Jogkövetés és társadalmi magatartás (Obedience to Law and Social Behaviour) (Akadémiai Kiadó 1980).

Sajó, András, ‘A jogi nézetek rendszere a gazdasági vezetők jogtudatában' (Legal Ideas in the Mind of Socialist CEOs) (1981) 24 Állam- és Jogtudomány 608-38.

Sajó, András, A jogtudat mikrokörnyezeti meghatározói (MTA ÁJTI 1981).

Sajó, András, Látszat és valóság a jogban (Illusion and Reality in Law) (Közgazdasági és Jogi Könyvkiadó 1986).

Sajó, András, Társadalmi-jogi változás (Socio-Legal Change) (Akadémiai Kiadó 1988).

Sajó, András, A jogosultság-tudat vizsgálata (A Study of the Rights Consciousness) (ELTE Szociológiai Intézet 1988-1989).

Sajó András, Constitutional Sentiments (Yale University Press 2011).

Samu, Mihály, 'Szocialista jogszemléletünk fejlödése' (The Development of Our Socialist Understanding of Law) (1975) 22 Magyar Jog 135-42. 
Schelsky, Helmut, 'A jogszociológia antropológiai és perszonális-funkcionális megközelítése' (An Anthropological and Personal-Functional Approach of Sociology of the Law) in Sajó András (ed.): Jog és szociológia (Közgazdasági és Jogi Könyvkiadó 1979) 155-70.

Studnicki, Franciszek, 'A jogszabályok kommunikációs problémái’ (The Problems of Communicating Laws) (1965) 40 Studia iuridica auctoritate Universitatis Pécs publicata 23-37.

Szabadfalvi, József, 'Törekvés egy jogfilozófiai szintézisre. Moór Gyula jogbölcselete' (Effort for a Synthesis in Legal Philosophy. The Legal Philosphy of Gyula Moór) in Loss Sándor et al.: Portrévázlatok a magyar jogbölcseleti gondolkodás történetéböl (Bíbor, 1995) 143-209.

Szabadfalvi, József, 'Viszony az elödökhöz. A marxista jogelmélet reflexiói a két világháború közötti magyar jogbölcseleti gondolkodásról' (A Relationship to the Predecessors. The Reflections of the Marxist Legal Theory on the Legal Philosophy of the Interwar Period) in Szabadfalvi József, A cselevöségi elmélettöl az újrealizmusig (From the Theory of Actions to the New Realism) (Gondolat-DE ÁJK 2004) 217-37.

Szabadfalvi, József, 'Revaluation of Hungarian Legal Philosophical Tradition' (2003) 89 Archiv für Rechts- und Sozialphilosophie 159-70.

Szabó, Imre, 'A jogbölcselet problémái. (Moór Gyula tanulmánya)' (Problems of Legal Philosphy [A Piece of Gyula Moór]) (1946) 1-2 Jogtudományi Közlöny 39-40.

Szabó, Imre, A burzsoá állam- és jogbölcselet Magyarországon (Bourgeois State- and Legal Philosophy in Hungary) (Akadémiai 1955).

Szabó, Imre, 'A jogtudat' (Legal Consciousness) in Szabó Imre, A jogelmélet alapjai (Akadémiai Kiadó 1971) 195-295.

Szabó, Miklós, 'Defensor dogmatis‘ (2004) 4 Világosság 35-48.

Szilágyi, Péter, 'Szabó Imre szocialista normativizmusa. Adalékok a szocialista normativizmus ideológiakirtikájához' (Imre Szabó's Socialist Normativism. Appendix to the Criticism of Socialist Normativism) (2003) 4 Jogelméleti Szemle < http://jesz.ajk.elte.hu/szilagyil6.html> accessed 23 October 2017

Szilágyi, Péter, 'Szabó Imre szocialista normativizmusa' (Imre Szabó’s Socialist Normativism) (2004) 4 Világosság 23-33.

Tamás, András, 'A jogtudat meghatározása, gyakorlati vonatkozások' (The Definition of Legal Consciousness, Practical Dimensions) (1969) 24 Jogtudományi Közlöny 15-24.

Tárkány-Szücs, Ernő, 'Magyar jogi népszokások' (Hungarian Legal Folk Customs) (Gondolat 1981).

Tomasic, Roman, The Sociology of Law (Sage 1987).

Tóth, Eszter Zsófia, Kádár leányai. Nök a szocialista idöszakban (Nyitott Könyvmühely 2010).

Varga, Csaba, 'A szocializmus marxizmusának jogelmélete. Hazai körkép nemzetközi kitekintésben' (The Legal Theory of Socialist Marxism. Domestic Overview in an International Context) (2004) 4 Világosság 89-116.

Varga, Csaba, 'Barna Horváth' in Horváth Barna, The Bases of Law/A jog alapjai (Szent István Társulat 2006) XVII-XVIII.

Varga, Csaba, 'Egy jogtudós útkeresése. Kulcsár Kálmán emlékezése Egerről, katonai ügyész pályakezdéséről, az akadémia jogtudomány-művelésben révbe érkezéséről' (The Way before a Legal Scholar. Memories of Kálmán Kulcsár on Eger, His start as a Military Prosecutor and the Arrival to the Academic Sphere of Legal Studies) (2013) 3 Jogelméleti Szemle 167-204.

Visegrády, Antal and Mária, Schadt, 'A pécsi joghallgatók jogtudatának néhány vonása' (Some Features of the Legal Consciousness of Law Students from Pécs) (1985) 34 Felsőoktatási Szemle $735-44$.

Vígh, József and Tauber, István, 'A bünözés megelözése és a jogtudat egyes problémái' (Crime Prevention and Certain Problems of Legal Consciousness) in Szük László (ed.), A bünmegelözésröl 1. Tanulmánykötet (Igazságügyi Minisztérium 1983) 64-111. 